\title{
ARAŞTIRMA/RESEARCH
}

\section{Kordomaların klinik ve histopatolojik özellikleri ve ayırıcı tanısı}

\author{
Clinical and histopathological characteristics and differential diagnosis of chordomas
}

Tuba Canpolat ${ }^{1}$, Nebil Bal ${ }^{1}$, Murat Çınar ${ }^{2}$

${ }^{1}$ Başkent Üniversitesi Hastanesi, Patoloji Anabilim Dalı, ${ }^{2}$ Ortopedi ve Travmatoloji Anabilim Dalı, Adana, Turkey

Cukurova Medical Journal 2016;41(4):771-776.

\begin{abstract}
Purpose: Chordomas are rare malignant bone tumours occuring in the midline of axial skeleton. We aimed to assess these tumors which has been diagnosed in our center in terms of clinical and pathologic characteristics, and differantial diagnosis difficulties.

Material and Methods: We retrospectively evaluated cinical and histopathologic characteristics of 10 chordoma patients diagnosed at pathology department of Baskent University Adana Teaching and Resarch Hospital between 2009 and 2014.

Results: The patients were consisted of men $(n=9)$ and women $(n=1)$ with the age of $61.3(38-84)$ years old. The localization of chordomas were the sacrococcygeal region at eight patients $(80 \%)$, lumbar vertebrae at one patient $10 \%)$ and clivus at one patient $(10 \%)$. The mean diameter was $4.68(2.5-7.5) \mathrm{cm}$. Histopathologically, majority of cases were "conventional chordoma" while one of them was "chondroid chordoma". Surgical excision was performed for all patients, only one case has recieved radiotherapy, and chemotherapy was given after surgery for one patient. Local recurrence was detected in three patients and distant metastasis (lung) was found in a patient and he died in a short time.

Conclusion: Because that chordomas are rare clinical bone tumours which can be treated efficiently by appropriate surgical excision, clinical and histopathological characteristics and differential diagnosis should be well known.

Key words: Chordoma, histogenesis, differential diagnosis.
\end{abstract}

\section{GİRİŞ}

Kordomalar, primitif notokord artıklarından gelișen, nadir görülen primer kemik tümörleridir. Görülme insidansları tüm malign kemik tümörleri içinde \%1-4 dür. Aksial aks boyunca çoğunlukla sakrokoksigeal
Öz

Amaç: Kordomalar, orta hat aksiyal iskelet sisteminde nadir görülen, malign kemik tümörlerdir. Merkezimizde tanı almış bu tümörlerin kliniko-patolojik özeliklerini ve ayırıcı tanı güçlüklerini değerlendirmeyi amaçladık.

Gereç ve Yöntem: Başkent Üniversitesi Adana Uygulama ve Araştırma Merkezi Patoloji Bölümü'nde 2009-2014 yılları arasında tanı almış 10 kordoma olgusunun klinik ve histopatolojik özellikleri retrospektif olarak değerlendirildi. Bulgular: Hastalar, yaş ortalamaları 61.3 ( 38-84) olan erkek $(n=9)$ ve kadın $(n=1)$ hastalardan oluşmaktadır. Kordomaların sekizi sakrokoksigeal (\%80), biri lumbar (\%10), biri ise 'clivus' üzerinde $(\% 10)$ yerleşimliydi. Tümör boyutu ortalama 4.68 (2.5-7.5) cm idi. Histopatolojik olarak 1 olgu "kondroid kordoma", diğerleri "konvansiyonel kordoma"dır. Hastalardan birisi sadece Radyoterapi almış diğer tüm olgularda cerrahi eksizyon uygulanmıştır. Bir hastaya cerrahi sonrası Kemoterapi verilmiştir. Hastaların 3'ünde nüks, birinde uzak organ (akciğer) metastazı saptanmıştır, bu hasta kısa süre sonra kaybedilmiştir.

Sonuç: Uygun cerrahi eksizyon ile etkin tedavi sağlanan nadir malign kemik tümörlerinden olan kordomaların klinik ve histopatolojik özelikleri ile ayırıcı tanısının iyi bilinmesi gerekmektedir.

Anahtar kelimeler: Kordoma, histogenezis, ayırıc1 tanı.

(\%50), sfeno-oksipital bölge (\%35) ve daha nadir olmak üzere hareketli vertebralarda (\%15) yerleşim gösterirler. Kordomalar yavaş büyüyen, düşük dereceli tümörler olarak kabul edilmekte olup nadiren uzak organ metastazı yaparlar, daha çok lokal nüks gösterirler ${ }^{1,2,3}$. Kordomalar 40-70 yaş

Yazışma Adresi/Address for Correspondence: Dr. Tuba Canpolat, Başkent Üniversitesi Hastanesi Patoloji Anabilim Dalı, Adana, Turkey Email: tuba.canpolat@yahoo.com.tr

Geliş tarihi/Received: 29.02.2016 Kabul tarihi/Accepted: 07.04.2016 
arasında ve erkeklerde daha sik görülür. Nadiren de çocuklarda görülür ${ }^{4}$. Tümörün ekstrasellüler matriks yapısı ve hücre morfolojisi fetal kordoma dorsalisi taklit eder. Bu histomorfolojik görünüm Virchow tarafindan ilk kez, 1857 yılında tanımlanmış ve tümörün embriyonel notokord artıklarından geliştiği teorisini ortaya koymuştur ${ }^{3,5,6}$. Histopatolojik olarak kordomalar epitelyal ve mezenkimal farklılaşma gösterebilir, özelikle kondroid morfoloji göstermesi, diğer kondroid morfoloji gösteren tümörler kondrosarkom ve kondroblastik osteosarkomlardan ayırımını gerektirir' ${ }^{6}$ Morfolojik, radyolojik ve immünhistokimyasal bulgular ile ayırıc1 tanıya gidilir. Yavaş büyüyen ve lokal invazyon yapan bu tümörlerin tedavisi cerrahidir. Yerleşim yeri, kitle boyutunun büyüklüğü nedeniyle uygun cerrahi yapilamayan olgularda lokal nüksler izlenirken tedaviye radyoterapi eklenir?

Kordoma nadir görülen uygun cerrahi eksizyon ile iyi prognoza sahip olan tümörlerdir. Cerrahi eksizyonu sınırlayan bu anatomik bölge yerleşimli tümörler değerlendirirken kordoma ve ayırıc1 tanısının bilinmesi ve klinik ve radyolojik bulguları ile birlikde değerlendirilmesi gerekir. Bu çalışmada bölümümüzde kordoma tanısı alan 10 olgu klinik, histopatolojik özelikleri ve ayırıcı tanısı açışından tartıșilmıștır.

\section{GEREÇ VE YÖNTEM}

Başkent Üniversitesi Patoloji bölümünde 2009-2014 yılları arasında tanı almış 10 kordoma olgusu retrospektif olarak incelenmiştir. Hastaların yaş, cinsiyet, tümör yerleşimi, boyut ve klinik bilgileri, değerlendirilmiştir (Tablo 1). Olgulardan ikisinde ince iğne aspirasyonu ve tüm hastalarin iğne biyopsileri bölümümüzde değerlendirilmiştir. Mikroskopik inceleme iki patolog tarafindan yeniden yapılmış, tüm olgulara tanı amaçlı; immünohistokimyasal yöntemle Keratin, Vimentin, S-100 ve EMA uygulanmıştır.

\section{BULGULAR}

Hastalarımızın yaş ortalaması 61.3 (38-84) dür. Dokuz hasta erkek, biri kadındır. Tümörlerin yerleşim yerine göre dağılımı 8 olgu sakrokoksigeal bölgede (\%80), 1 olgu lumbar bölgede (\%10) 1 olgu ise clivus üzeri $(\% 10)$ yerleşimlidir. Hastaların yedisi bel ağrısı şikayeti ile, en büyük tümör boyutuna sahip hastamız ağr1 yanı sıra kabızlık şikayeti ile, clivus yerleşimli olgumuz kulak ağrısı şikayeti ve lumbar vertebra yerleşimli olgumuzda ise ağrı ile birlikde bacakda uyuşukluk hissi şikayeti ile hastanemize başvurmuştur.

Tablo 1. Olguların demografik özellikleri ve tümör karakteristikleri

\begin{tabular}{|l|c|c|c|c|c|}
\hline Olgu & Cinsiyet & Yaş & Tümör Lokalizasyonu & Boyut (Mm) & Semptom \\
\hline 1 & E & 42 & sakrokoksigeal & $75 \times 69$ & Ağr1, kabılzlik \\
\hline 2 & E & 51 & sakrokoksigeal & $27 \times 2.3$ & Bel ağr1s1 \\
\hline 3 & E & 84 & sakrokoksigeal & $37 \times 31$ & Bel ağr1s1 \\
\hline 4 & E & 38 & sakrokoksigeal & $35 \times 20$ & Bel ağr1s1 \\
\hline 5 & E & 72 & L2 vertebra & $25 \times 22$ & Ağr1, uyuşukluk \\
\hline 6 & E & 57 & sakrokoksigeal & $36 \times 27$ & Bel ağr1s1 \\
\hline 7 & E & 62 & sakrokoksigeal & $52 \times 48$ & Bel ağr1s1 \\
\hline 8 & E & 71 & sakrokoksigeal & $61 \times 45$ & Bel ağr1s1 \\
\hline 9 & K & 64 & sakrokoksigeal & $55 \times 48$ & Bel ağr1s1 \\
\hline 10 & E & 72 & klivus & $65 \times 50$ & Kulak ağr1s1 \\
\hline
\end{tabular}

Tümör boyutu ortalama 4.68 (2.5-7.5) cmdi. İki olguda ince iğne aspirasyonu uygulanmış olup, bu yaymalarda müsinöz matriks içeren zeminde gruplar yapan fizeliferöz hücreler görülmüştür.Kordoma tanısı alan bu olgulardan da iğne biyopsileri yapılmıştır. Olguların mikroskopik incelenmesinde; gevşek müsinöz mikzoid stromada, yuvarlak oval geniş sitoplazmalı fizeliferöz hücre grupları ve yer yer daha hiperkrom küçük çekirdekli hücrelerden olușan tümör izlenmiștir (Resim 1).İmmünohistokimyasal yöntemle uygulanan, Keratin (Resim 2) , S-100 protein ( Resim 3) Vimentin, EMA antikorları ile tüm olgularımızda pozitif boyanma görülmüştür. S-100 olguların tamamında aynı şiddet ve yoğunluk da boyanmamıştır. Klivus yerleşimli olgumuz Kordoid Kordoma histolojik varyant1 ile uyumludur (Resim 4). Diğer olgular konvansiyonel varyant ile uyumlu 
bulunmuştur. Hastalardan birisi sadece radyoterapi (hasta no 7) almış diğer tüm olgularda cerrahi eksizyon uygulanmıştır. Bir hastaya (olgu no 8) cerrahi sonrası Kemoterapi verilmiştir. Hastaların 3. de nüks, birinde uzak organ (akciğer) metastazı saptanmıştır. Metastatik olan olgumuz tedavi başlangıcında kısa bir süre ( 10gün sonra) sonra ölmüştür.

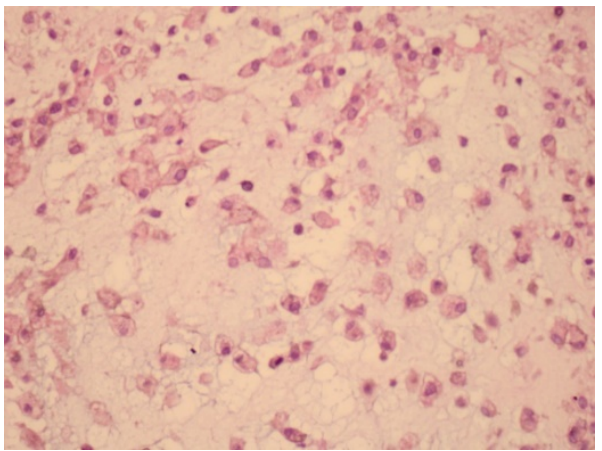

Resim 1: Gevşek müsinöz mikzoid stromda yuvarlak oval geniş sitoplazmalı fizeliferöz hücre gruplar1 H.EX200

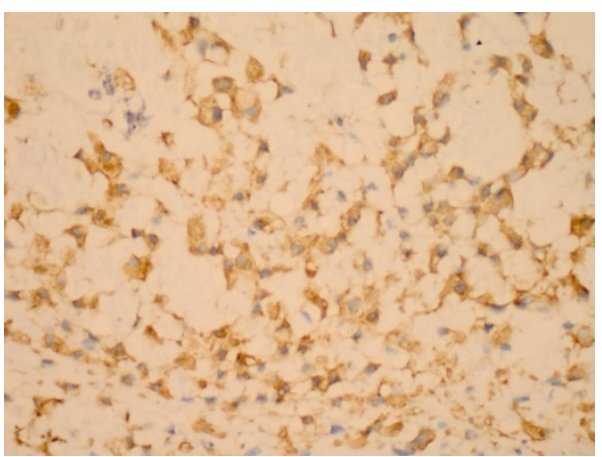

Resim 2: Keratin ile boyanan fizeliferöz hücreler Keratin x 200.

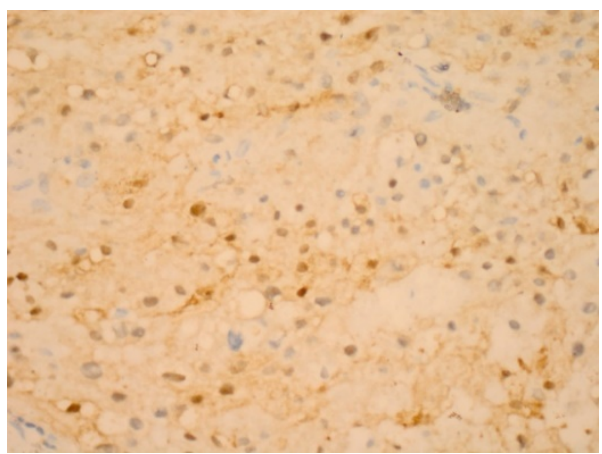

Resim 3: S-100 ile boyanan fizeliferöz ve bazoloid hücreler S-100X200

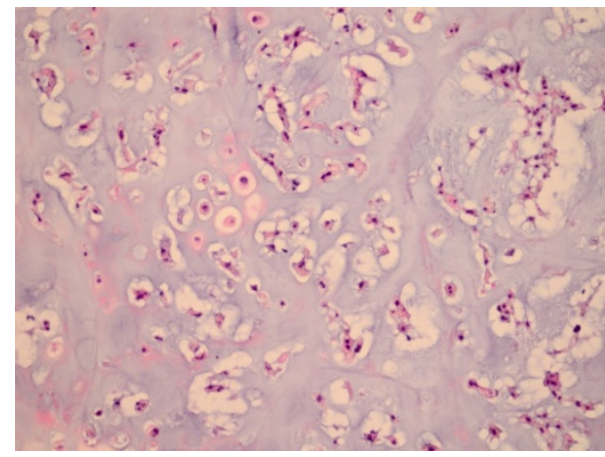

Resim 4: Kondroid alanları belirgin kordoid kordoma H.EX 200

\section{TARTIŞMA}

Kordomalar, kemiğin, oldukça nadir görülen tümörleridir. Görülme insidansları \%1-4 arasındadır. Aksial aks boyunca görülmeleri, tümörün notokord artıklarında gelişmiş olduğunu fikrini destekler ${ }^{1-4}$. İlk kez 1857 y1lında Virchow; hücre içi köpüksü vakuoller içeren fizaliferöz hücreleri tanımlamış ve kordomaların vertebra gövdesinin diferansiye olamayan kartilaj dokusundan geliştiği hipotezini ileri sürmüştür ${ }^{5,6}$. Tümörün notokard artıklarından geliştiği bilinmekle birlikte kalıntıların nasıl tümöre dönüştügü bilinmemektedir. Branchyury bir nükleer transkripsiyon faktörü olup T-box gen ailesinin bir üyesidir. Embriyolojik olarak notokord gelişimde rol alır, kordoma patogenezinde saptananan ilk spesifik moleküldür. Branchyury mutasyonları vertebra malformasyonlarına, bu genin disregülasyonu ise kordomalara neden olmaktadir. İmmnünohistokimyasal yöntemle aksial kordoma tanısında $\% 90-100$ yüksek duyarlılık ve $\% 100$ özgül olarak kullanılan ilk moleküler belirleyicidir ${ }^{6,7,8} 9$.

Kordomalar yavaş büyür ve klinik bulguları tümörün yerleşim yerine ve boyutuna göre değişkenlik gösterir. Kordomaların yarından fazlası sakrum yerleşimlidir. İkinci sıklikta klivus (\%35) daha nadiren de (\%1-6) hareketli vertebralarda servikal torasik ve lumbar vertebralardan gelișir1,3,4. Bizim olgularımız sekizi (\%80) sakrokosigeal bir tanesi klivus (\%10) bir olgumuz ise (\%10) lumbar vertebra yerleşimlidir.

Sakrokoksigeal yerleşim gösteren vakaların yaş ortalaması 50-70 arasında iken nadiren 30 yaş altında görülür. Sfenooksipital yerleșimli olan olgular sakrokoksigeal bölge yerleşimli olgulardan 1 dekat 
daha önce saptanırlar ${ }^{3,10}$. Bizim olgularımızın büyük kısmı sakrokoksigeal yerleşimlidir. Kadın /Erkek oranı kranial ve sakrokoksigeal bölge için literatürde çoğunlukla $2 / 1$ ve daha yüksek oranda erkeklerde görülmektedir. Olgularımızın 1 tanesi kadın diğerleri erkektir. Literatürde kadın cinsiyetin bağımsız bir kötü prognostik parametre olduğundan bahsedilmektedir ${ }^{11}$. Bizim serimizdeki tek kadın olgumuz da geç tanı almış, uzak organ metastazı yapmış ve tadaviden çok kısa süre sonra kaybedilmiştir. Birçok seride semptomların başlamasından tanı anına kadar geçen süre ortalama 15 aydır (2 hafta-8yıl). Sakrokokosigeal bölge tümörleri anotomik olarak önlerindeki boşluğa doğru yavaş ve ağrisız büyüdükleri için geç dönemde ve büyük boyutlara ulaştıklarında semptom verirler ${ }^{3}$. Bizim olgularımızda tümör boyutu ortalaması 4.68 cm iken en büyük tümör boyutu 7.5 cm'dir. Çolpan ve ark bildirdiği 6 ay gibi kısa sürede gelişen 40 X 25 $\mathrm{cm}$ boyutlara ulaşan dev sakrokokosigeal yerleşimli kordomalar da nadir olarak mevcuttur ${ }^{12}$.

Hastalar güç kaybı (\%55), ağrı ve palpabl kitle (\%35), sakral ağrı ve duyarlılık (\%25), konstipasyon ve üriner disfonksiyon (\%20) gibi semtoplarla kliniğe başvurabilir ${ }^{3}$. Bizim olgularımız en sık bel ve sakral ağrı şikayeti ile başvurmuştur. Sakrokoksigeal bölge yerleşimli tümörler, çevreye organlara rektuma doğru büyür, ancak presakral fasia nedeniyle rektuma geçemezler $^{6}$. En büyük tümör boyutuna sahip olgumuzda ağr1 şikayeti ile birlikte muhtemel kitle etkisi nedeniyle kabızlık şikayeti ile kliniğe başvurmuştur. Nörolojik semptomlar hareketli vertebra tutulumu olan olgularda sakrokoksigeal bölge yerleşimine göre daha sıktır. Lumbar vertebra yerleşimli olgumuz da ağrı ile birlikte bacakda uyuşukluk şikayeti olmuştur. Paralizi geç komplikasyondur. Kafa tabanı yerleşimli olgularda baş ağrısı çift görme, görme bozuklukları, piramidal sistem bozukluklarına bağlı semptomlar disfaji, hava yolu obstrüksiyonu, geçici iskemik atak gibi nörolojik semptomlar görülebilir?

Sakrum ve sakrum dışı lezyonların radyolojisi benzerdir. Standart grafilerde erken evrede lezyonu tesbit etmek zordur. Erken evrede Bilgisayarlı Tomografi (BT) ve Manyetik Rezonans (MR) ile tanı konulabilir. Vertebralarda kitle santral yerleşimli litik bir lezyon oluşturur. Geniş osteolitik lezyonlar fokal amorföz kalsifikasyonlar içeren reaktif kemik formasyonları içerir. Sakrokoksigeal lezyon pelvik kaviteye, gluteal kaslara invaze olabilir. MR, tümör yayılımını, lokal rekkürensi, skar ile rezidü ayırımında kullanılır. Radyolojik ayırıcı tanıda metastatik tümörler, primer sekonder spinal tümörler; başta Dev hücreli tümör, Multiple myelom, kondrosarkom nörojenik tümörler, Paget gibi hastalıklar yer alır ${ }^{3,5,7,13,14}$. Kordomalar ile kondrosarkomların radyolojik olarak ayırımının yapılabileceği ortaya koyan çalışmalar özelikle kafa tabanı yerleşimli olgularda bildirilmektedir. Kordomaların orta hatta klivus çevresinde yerleşmekte bu karşın kondrosarkomların paramedian ve petröz kemik içine yerleşmektedir. Ancak Pamir ve arkadaşlarının çalışmalarında bu iki tümörün her iki lokalizasyonda da yerleştiğini göstermişlerdir ${ }^{5}$.

Kordomalar makroskopik olarak, iyi sınırl, lobüler gri kahve renkte, jelatinöz yumuşak doku kitlesi görünümündedir. Fokal kistik alanlar ve kanama alanları içerir. Tranlüsen, jelatinöz makroskopik görünüm kondrosarkom ve müsinöz karsinomlar da benzer özellikdedir. Mikroskopik olarak kordomalar normal notokordun gelişim evrelerinde izlenen hücreleri içeren lobüle iyi sinırlı tümörlerdir. Zeminde bazofilik ekstrasellüler matriks müsin içerir. Fizaliferöz hücreler geniş vakuoler yer yer ise şeffaf sitoplazmalı veziküler çekirdekli hücrelerdir. Tümörde izlenen diğer hücre ise küçük belirgin olmayan çekirdek içeren yuvarlak oval daha bazofilik görünümlü hücreleridir. Mitoz yoktur ya da çok nadirdir. Arada kemik ve kıkırdak doku izlenebilir. Tümör hücreleri immünohistokimyasal yöntemle keratin, EMA, S-100 protein ve vimentin ile boyanırlar. Bizim olgularımızda da epitelyal belirteçler ile vimentin ve S-100 protein pozitif saptand 1 1,3,4,5,7,10.

Ayırıcı tanıda; anotomik lokalizasyonu mikroskopik görümleri göz önüne alındığında kondrosarkom, liposarkom, Taşlı yüzük hücreli karsinom metastazları ve Miksopapiller ependimom başta yer alır. Keratin boyanması benzer morfolojik görünüm içeren kondrosarkom ve liposarkomlarda görülmez ve ayırıcı tanıda önemli belirteçlerdir. Taşlı yüzük hücreli karsinomlarda keratin ile boyanma görülürken S-100 protein ve vimentin ile boyanma görülmez. Miksopapiller ependimomlarda da S-100, keratin ile boyanma görülmez 2,3,4,5,15,16. Tüm olgularımızda keratin ve S-100 ile boyanma saptanmıştır. İnce iğne aspirasyon sitolojilerinde de histomorfolojik görünümlerindeki gibi mikzoid matriks ve fizeliferöz hücreler görülülebilir. İki olgumuzda kitleye ince iğne aspirasyonu yapılmış olup sonra iğne biyopsi örnekleri değerlendirilmiştir. Yaymalarda fizeliferöz hücrelerin varlığ1 nedeniyle 
tanı kordoma lehine değerlendirilmiștir.

Kordomalarda; konvansiyonel, kondroid ve dediferansiye olmak üzere üç histolojik varyant tanımlanmıştır. Konvansiyonel (klasik) tip, fibröz septalarla sarılı yuvarlak oval vakuole sitoplazmalı fizaliferöz hücreleri içerir. Kordoid kordoma varyantı özelikle sfenooksipital bölge yerleşimli olup kartilajinöz komponenti daha belirgindir. Klivus yerleşimli olgumuz kondroid alanlardan zengin görünümde, Kordoid kordoma varyantı ile uyumludur. Kordoid kordomalar konvansiyonel kordomalardan daha iyi prognoza sahiptir. Dediferansiye kordoma varyantı ise çoğunlukla sakrokoksigeal yerlessimli, az diferansiye ve mezenkimal hücre benzeri morfoloji gösterir. Dediferansiye kordomalar daha yüksek metastaz riski taşıdıklarından kötü prognoza sahiptirler ${ }^{6,10,17}$.

İğne biyopsi materyallerinde kondroid farklılaşma gösteren kordomaları kondrosarkom ve kodroblastik osteosarkom gibi tümörlerin ayırımı güçtür. Klinik ve radyolojik bulgular olmaksızın kesin tanı bazen imkansızdır. Özellikle sfenooksipital bölge yerleşimli kordomalarda kondroid diferansiasyonun belirgin olması nedeniyle kondrosarkom ayırımı dikkat gerektirir. Kondrosarkomlar en s1k altınc1 dekatta omuz, pelvis, proksimal femur bölgesin de görülürken \%2 gibi bir oranda kordomaları s1k gördüğümüz sakrokoksigeal bölgede de görülebilir. Kondrosarkomlar mikroskopik olarak hiyalinize ve mikzoid zeminde atipik kondrositleri içereren lakünler içerir, mikzoid kondrosarkomlarda neoplastik kondrositler küçük olup adalar oluşturmazlar, buna karşıı kordomalarda hücreler daha iri geniş eozinofilik sitoplazmalıdır. Kordoma ve kondrosarkomların klinik davranışları, tekrarlama ve metastatik özelikleri birbirinden çok farklıdır. Bu durunda kordoma ve kondrosarkom ayırımı önemli ve benzer morfolojileri nedeniyle güçtür. Kesin ayırım için immün belirteçler kullanılmalıdır. S-100 ve vimentin her iki tümörde pozitif saptanırken keratin ve EMA ile boyanma kordomaları bu tümörden ayırır. Sitolojik materyaller de ise bu iki tümörüm ayırımı çok güçtür. Fizaliferöz hücreler kordomalar için spesifiktir ancak diagnostik değildir, mikzoid kondrosarkomlarda da görülebilir. Kondroblastik osteosarkomlarda ise osteoidin görülmemesi histolojik olarak ayırıcı tanıda zorluk yaratırken, osteosarkomların adelosan yaşta görülmesi ve radyolojik görünümü, immün histokimyasal olarak S-100 negatifliği ayırıcı tanıda yardimcidir ${ }^{18,19}$.
Tedavi ön planda cerrahi eksizyon ve radyoterapi veya kombine tedavilerdir. Kordomalarda ilk cerrahi girişimde tümörün tam olarak çıkartılması, nüks ihtimalini neredeyse imkânsız hale getirmesi nedeniyle iyi prognoz sağlanması bakımından önemlidir. Cerrahi disseksiyonun tümörün radyolojik sınırının bir vertebra üzerine kadar uzatılması tavsiye edilmektedir. Bununla birlikte geniş bir diseksiyon uygulanması idrar ve gayta inkontinans1 da dahil olmak üzere ciddi nörolojik defisitler ve önemli morbiditelere yol açabilmektedir. Cerrahi olarak tam çıkarılamayan olgularda lokal nüksler sık görülür. Tümörlerin anotomik yerleşimleri çok önemli olup, geniş cerrahi sınıra ulaşmak için barsak mesane ve cinsel fonksiyon bozulabilir. Radyoterapi cerrahi rezeksiyonu mümkün olmayan olgularda ilk seçenektir ${ }^{17-21}$.

Prognostik faktörler arasında tümör boyutu, cerrahi eksizyon sınırları, nekroz ve yüksek proliferasyon indeksi yer almaktır $4,10,12,13,17$. Ancak genç yaş ve geniş cerrahi eksizyon, tek ve en iyi prognostik parametredirr, ${ }^{5,11}$. Düşük dereceli tümörler olması nedeniyle kordoma metastazları, nadiren ve çok ileri aşamalarda ortaya çıkarlar. Uzak metastazlar over, cilt nadiren de akciğerlere olur ${ }^{15,22}$. Olgularımızdan biri tanı aldıktan kısa bir süre sonra akciğer metastazı saptanmış kemoterapi planlanmış ancak tanı sonrası 10. günde eks olmuştur. Kordomalar, nadir görülen ve yavaş büyüyen tümörlerdir, cerrahi eksizyon hastanın prognozunu belirleyen en önemli faktördür. Erken tanı alamayan olgularda yerleşim yeri tedaviyi sinırlamaktadır. $\mathrm{Bu}$ nedenle hastalığın klinik, radyolojik ve histopatolojik özeliklerinin iyi bilinmesi ve ayırıcı tanı önem kazanmaktadır. Histopatolojik olarak ayırıcı tanida yer alan lezyonların benzer morfolojik özelikler göstermesi, hastaların klinik ve radyolojik verileri ile birlikde değerlendirmeyi gerektirir.

\section{KAYNAKLAR}

1. Mirra JM, Rocca CD, Nelson SD, Chordoma MF. Tumors of soft tissue and bone. In World Health Organization Classification of Tumors. Pathology and genetics (Eds CMD Fletcher, KK Unni, F Mertens):316-7. Lyon, IARC Pres. 2004.

2. Lauer SR, Edgar MA, Gardner JM, Sebastian A, Weiss SW. Soft tissue chordomas. a clinicopathologic analysis of 11 cases Am J Surg Pathol. 2013;37:71926.

3. Papagelopoulos PJ, Mavrogenis AF, Galanis EC, Savvidou OD, Boscainos PJ, Katonis PG et al. Chordoma of the spine: clinicopathological features, 
diagnosis, and treatment. Orthopedics. 2004;27:125663.

4. Hoch BL, Nielsen GP, Liebsch NJ, Rosenberg AE. Base of scull chordomas in children and adelescents. Am J Surg Pathol. 2006:30:811-8.

5. Pamir N. Kordomaların biyolojisi. Türk Nöroşirürji Dergisi. 2006;16:6-10.

6. Walcott BP, Nahed BV, Mohyeldin A, Coumans JV, Kahle KT, Ferreira MJ. Chordoma: current concepts, management, and future directions. Lancet Oncol. 2012;13:69-76.

7. Wang L, Wu Z, Tian K, Li G, Zhang J. Clinical and pathological features of intradural retroclival chordoma. World Neurosurg. 2013;13:314-8.

8. Shen J, Li CD, Yang HL, Lu J, Zou TM, Wang DL, Deng M. Classic chordoma coexisting with benign notochordal cell rest demostrating different immunohistological expression paterns of brachyury and Galectin-3. J Clin Neurosci. 2011;18:96-9.

9. Lantos JE, Agaram NP, Healey JH, Hwang S. Recurrent skeletal extra-axial chordoma comfirmed with brachyury :Imaging features and review of the literature. Skelatal Radiol. 2013;42:1451-9.

10. Naka T, Boltze C, Sami A, Herold C, Ostertag H, Iwamoto Y. Skull base and nonskull base chordomas. Cancer. 2003;98:1934-41.

11. Makhdoomi R, Ramzan A, Khursheed N, Bhat S, Baba K, Mohsin R et al. Clinicopathological characteristics of chordoma: an institutional experience and a review of the literature. Turk Neurosurg. 2013;23:700-6.

12. Colpan E, Caglar S, Kahiloğulları G, Erekul S, Sekerci Z. Unusually fatal complication of large sacral chordoma: a case report. Turk Neurosurg. 2004;14:84-6.

13. Gangadhar K, Santhosh D. Radiopathological evaluation of primary malignant skull tumors: a review.Clin Neurol Neurosurg. 2012;114:833-9.

14. Orguc S, Arkun R. Primary tumors of the spine. Semin Musculoskelet Radiol. 2014;18:280-99.

15. Canda S, Kurtoğlu B, Kuyucuoğlu M.F, Güner E.M, Sade M. Kordomaların doku kimyasal ve immün dokukimyasal özellileri ve bir olgu sunumu. Türkiye Ekopatoloji Dergisi 1998;4:42-5.

16. Ardıç F,Arabacı E, Bilir E, Pal I. Kordoid kordoma: olgu sunumu. Acta Oncologica Turcica. 2003;36:103.

17. Ouyang T, Zhang N, Zhang Y, Jiao J, Ren J, Huang $\mathrm{T}$ et al. clinical characters, immunohistochemistry, and outcomes of 77 patients with skull base chordomas. World Neurosurg. 2014;81:790-9.

18. Akbolat N, Yildirım H, Poyraz K. Sakral chondroblastic osteosarcoma misdiagnosed as chondrosarcoma and chordoma. 2007;37:243-9.

19. Yaycioğlu S, Ak H. Sakral kordomalarda cerrahi rezeksiyon boyutlar1: olgu sunumu. ADÜ Tip Fakültesi Dergisi. 2010;11:43-4.

20. Guo W, Tang X, Zang J, J Tao. One -stage total en bloc sacrectomy. Spine. 2013;38:626-31.

21. Aydınlı U. Sakrum ve ileum primer tümörlerinin tanı ve tedavisi. Acta Ortop Traumatol Turc. 1998;32:278-82.

22. Altaner S, Ozyılmaz F, Cakır B, Kutlu A.K. Vertebral kordoma : olgu sunumu. Ankara Patoloji Bülteni. 1999;16:45-8. 